\title{
ETYKA W RESUSCYTACJI
}

\section{ETHICS IN RESUSCITATION}

\author{
Magdalena Napiórkowska-Orkisz, Jolanta Olszewska
}

DOI: https://doi.org/10.20883/pielpol.2017.70

\begin{abstract}
STRESZCZENIE
Celem pracy jest przedstawienie głównych zasad etycznych i odniesienie ich do dylematów związanych z podjęciem lub zaniechaniem resuscytacji w neonatologii.

Szybki postęp w neonatologii zwiększył odsetek przeżywalności noworodków. Przed 1970 rokiem odstąpienie od leczenia skrajnych wcześniaków było „normą". Przełomowy dla postaw wobec noworodków był rok 1981 i śmierć dziecka „Baby Doe”. Zapoczątkowano wtedy epokę nakazu - wszystko, co możliwe dla utrzymania dziecka przy życiu, musi być zrobione. Dopuszcza się wstrzymanie leczenia, jeśli nie ma szansy na przeżycie noworodka. Znamy cztery główne zasady etyczne. Prawo pacjenta do wyrażania zgody na proponowane leczenie dotyczy osób świadomych, zdolnych do podejmowania decyzji. Noworodek jest pacjentem niezdolnym do wyrażenia swej zgody na proponowane leczenie czy resuscytację. Głos w jego imieniu przejmują rodzice oraz zespół leczący. Zasada nieczynienia krzywdy oznacza działanie w najlepszym interesie pacjenta. W myśl tej zasady resuscytacja nie powinna być podejmowana w sytuacjach nierokujących powodzenia. Należy zrezygnować z uporczywej terapii. Zasada sprawiedliwości - resuscytacja powinna być dostępna dla każdego człowieka, jeśli tylko jest w stanie przynieść mu korzyść. Leczenie pacjenta powinno zawsze odbywać się z poszanowaniem jego osoby.

Oprócz prawa do bycia szczęśliwym i zdrowym człowiek ma przede wszystkim prawo do życia. Według nauczania Kościoła katolickiego przyznajemy osobowe prawa człowiekowi już od chwili zapłodnienia. Te same prawa głosi zasada świętości życia ludzkiego. Życie jest darem Boga, należy je chronić, gdyż jest cenne samo w sobie.
\end{abstract}

SŁOWA KLUCZOWE: etyka, resuscytacja, neonatologia, noworodek.

\section{Wprowadzenie}

„Jakość, wysokie kwalifikacje, wiedza są bardzo ważne w tym zawodzie. Jednak bez właściwej postawy moralnej przesyconej wartościami duchowymi pielęgniarstwo przestaje być tym, czym być powinno. Sama istota zawodu wymaga, by równolegle z wiedzą postawić przed sobą wizję: prawda, dobro, miłość".

Etyka jest nauką o wyborach [1]. Jej przedmiotem są normy, wartości, oceny i zachowania moralne. Nie zmienia ona systemów uznawanych wartości, lecz po-

\section{ABSTRACT}

The aim of this study is to present the main ethical principles and referring them to the dilemmas of taking, or omitting resuscitation in neonatology.

Rapid advances in neonatology increased the percentage of survival of newborns. Before 1970 withdrawal from the treatment of extreme newborns was the 'norm'. Groundbreaking for attitudes toward newborns was 1981 and the death of the child 'Baby Doe'. Then initiated the era of the command - everything possible to keep the child alive must be done. It is allowed to suspend treatment if there is no chance of survival of the newborn. We know the four main ethical principles. Patient's right to consent to the proposed treatment applies to people informed, able to make decisions. The infant is a patient unable to express their consent to the proposed treatment or resuscitation. The decision belongs to the parents and the medical team. The principle of not doing harm - means acting in the best interest of the patient. According to this principle, resuscitation should not be taken in situations not promising success. One should therefore abandon persistent therapy. The principle of justice - resuscitation should be available to every human being, if it is able to bring him/her benefits. Treatment should always be implemented with respect to this person.

In addition to the human right to be happy and healthy - his/ her first and foremost right is the right to live. According to the teaching of the Catholic Church, we recognize the personal rights of a man from the moment of fertilization. The same law states the principle of the sanctity of human life. Life is a gift from God and it should be protected as it is valuable itself.

KEYWORDS: ethics, resuscitation, neonatology, newborn.

zwala je zrozumieć, uznać świadomie. Jej zadaniem jest rozważanie, która spośród możliwych odpowiedzi na zadane pytanie jest słuszna [2]. Pytania: „Czy dziecko powinno przyjść na świat mimo wady letalnej?”, „Czy aborcja/eutanazja powinna być dozwolona?”, „Czy warto ratować noworodki urodzone na granicy zdolności do życia?" są najtrudniejszymi, jakie neonatologia stawia przed ludzkością. Odpowiedzi na te pytania i wybory, jakie mają się dokonać, są bardzo ważne [1]. Etyka ma dostarczać norm postępowania. Jednak ustalenie cech 
wspólnych dla wszystkich norm uznanych za moralne jest zadaniem niemożliwym do wykonania [3]. Dlatego też każdy człowiek posiada sumienie (szczególny zespół intuicji etycznych). Jest ono nieomylne. Sumienie przenosi ogólny porządek cenionych przez nas wartości na grunt naszych indywidualnych przeżyć. Pozwala nam stawić czoło trudnym sytuacjom, w których konieczne jest podjęcie decyzji i odpowiednie działanie. Dzięki sumieniu mamy pewność, że w konkretnej sytuacji podjęliśmy słuszną decyzję. Sumienie jest najszlachetniejszym z naszych zmysłów [2]. Etyka starożytna definiowana jako nauka o tym, co należy wybierać, a co odrzucać, nie zdołała odpowiedzieć do końca na zadane pytania [4]. Bioetyka jest dyscypliną filozoficznej etyki szczegółowej, snuje ona refleksje na tematy poruszane w medycynie, przywoływane w przysiędze Hipokratesa, ale także problemy niesione przez rozwój nauk biomedycznych. Zadaniem bioetyki jest ustalenie norm dotyczących działań medycznych, które ingerują w proces powstania życia człowieka, jego egzystencji i śmierci [5].

Resuscytacja jest to zespół czynności mających na celu przywrócenie funkcji życiowych poszczególnych narządów i układów - rozprężenie płuc i utrzymanie prawidłowego utlenowania ustroju (szczególnie ośrodkowego układu nerwowego), zapewnienie odpowiedniego rzutu serca i perfuzji obwodowej, utrzymanie neutralnej temperatury ciała [6]. W Polsce rodzi się rocznie około 35 tysięcy wcześniaków, znaczna część z nich wymaga postępowania resuscytacyjnego w pierwszych minutach swojego życia [7]. Działań ułatwiających podjęcie własnej czynności oddechowej bezpośrednio po urodzeniu wymaga $10 \%$ noworodków. Odsetek ten wzrasta co roku, szczególnie w przypadku noworodków z masą ciała < 1500 g. Pełnego postępowania reanimacyjnego wymaga $1 \%$ noworodków. Większe ryzyko resuscytacji dotyczy dzieci urodzonych przed 35. tygodniem ciąży [8].

\section{Proces upodmiotowienia noworodków}

Przez tysiące lat medycyna dysponowała ograniczonymi możliwościami terapeutycznymi, szczególnie w zakresie pediatrii. Połowa lat 60. ubiegłego stulecia to początek kształtowania się nowej specjalizacji medycznej - neonatologii. Wyodrębnienie jej wynikało z potrzeby zmierzenia się z problemem wysokiej śmiertelności noworodków i nieprzypadkowo stało się to w czasie dynamicznego rozwoju technologicznego medycyny. Kamieniami milowymi medycyny okresu noworodkowego stały się:

- respirator umożliwiający oddychanie zastępcze,

- inkubatory zapobiegające utracie ciepła,

- rozwój farmakologii (surfaktant),
- $\quad$ wdrożenie pełnego karmienia pozajelitowego,

- rozwój kardiochirurgii, neurochirurgii i diagnostyki obrazowej [9].

Ten szybki postęp nie tylko umożliwił wielu noworodkom przetrwanie niebezpiecznego okresu adaptacji, ale także zwiększył odsetek przeżywalności wcześniaków. Jeszcze 50 lat temu noworodki urodzone poniżej 34. tygodnia ciąży nie miały szansy przeżycia. Dziś podejmuje się próby ratowania dzieci urodzonych powyżej 23. tygodnia ciąży [9]. Początkowo sukcesom neonatologii nie towarzyszyło podmiotowe traktowanie noworodków. Przed 1970 rokiem odstąpienie od ich leczenia było „normą”. Być może dlatego, że ówczesne społeczeństwo nie przypisywało noworodkom statusu osoby [10]. Przełomowy dla postaw świata medycznego i społeczeństwa wobec noworodków był rok 1981 i przypadek dziecka nazwanego „Baby Doe”. W Stanach Zjednoczonych (w Bloomington) urodziło się dziecko z zespołem Downa i przetoką między przełykiem i tchawicą. Nieodpowiednio ukształtowany przewód pokarmowy uniemożliwiał karmienie. Problem mógł być rozwiązany poprzez zabieg operacyjny i żywienie pozajelitowe. Rodzice odmówili zgody na operacje, uzasadniając to najlepszym interesem chorego dziecka i całej rodziny. Szpital dwakroć zwrócił się do sądu o zezwolenie na przeprowadzenie operacji. Sąd okręgowy oraz Sąd Najwyższy w stanie Indiana uznały prawo rodziców do odmowy wyrażenia zgody na operację. Sprawa zyskała szeroki oddźwięk w opinii publicznej. Kilka rodzin zaoferowało natychmiastową adopcję Baby Doe. Chłopiec zmarł po 6 dniach. Opisana sytuacja zapoczątkowała w neonatologii epokę nakazu - wszystko, co możliwe dla utrzymania dziecka przy życiu, musi być zrobione. Dopuszcza się wstrzymanie leczenia ze względu na jego nieludzki charakter, jeśli nie ma szansy na przeżycie noworodka [11].

\section{Prawo człowieka do bycia zdrowym i szczęśliwym}

Życie w zdrowiu i szczęściu jest celem każdego człowieka. Wartości te są niemalże najważniejszymi z dóbr naszej egzystencji. Zwolennicy aborcji (w przypadku negatywnych wyników diagnostyki prenatalnej) odnoszą się do racji, iż każde dziecko ma prawo przyjść na świat zdrowe fizycznie i psychicznie [12]. Posuńmy się dalej w tych rozważaniach. Skoro embrionowi przysługuje tego rodzaju prawo, moglibyśmy pokusić się o pogląd, iż prawo to przysługuje również każdemu noworodkowi urodzonemu przedwcześnie. Z przeżywalnością noworodków urodzonych na granicy zdolności życiowych łączą się zagadnienia późniejszych negatywnych następstw w stanie ich zdrowia, takich jak: uszkodzenie wzroku, słuchu, zaburzenia rozwoju psychomotorycz- 
nego i intelektualnego [13]. W przypadku tych zaburzeń odstąpienie od resuscytacji mogłoby nie być aktem moralnie złym, a wręcz przeciwnie - mogłoby zdawać się być godnym moralnej aprobaty. Niepodjęcie działań resuscytacyjnych przedstawia się w świetle wyboru mniejszego zła (śmierci dziecka) w miejsce większego zła (jego życiu w szeroko rozumianym kalectwie). Jednakże prawo do bycia zdrowym należy rozumieć jako prawo powszechne, przysługujące każdemu człowiekowi - przez całe jego życie. Nie widać bowiem racji, dla których wcześniak miałby być traktowany wyjątkowo. Wobec tego prawa dojrzały człowiek, który w ciągu swojego życia stracił zdrowie, mógłby rościć sobie prawo do eutanazji [12]. Wszystko to rodzi poważne kontrowersje.

Prawo do bycia szczęśliwym - w tym zakresie mieszczą się: materialny dobrobyt, pomyślne stosunki z innymi ludźmi, społeczna stabilizacja, możliwość realizowania swoich planów, ale także wspomniane już zdrowie fizyczne i psychiczne. Prawo do bycia szczęśliwym należy rozumieć jako powszechne - przysługujące zarówno dzieciom, jak i ich rodzicom [12]. Noworodek urodzony na granicy zdolności życiowych może być dla rodziców spełnieniem marzeń o rodzicielstwie, niezależnie od stanu zdrowia dziecka. Bądź może być problemem, powodując konieczność skupienia na nim swojej uwagi, wszystkich nakładów finansowych, absolutnego poświęcenia dotychczasowego życia, rezygnacji ze swoich pasji, kariery zawodowej. W takim założeniu rozpatrywany problem przybiera postać pytań: „Co jest szczęściem dla rodzica, a czym jest ono dla dziecka?”, „Czy rodzicom skrajnego wcześniaka przysługuje w imię ich własnego szczęścia prawo do decyzji o przerwaniu bądź zaniechaniu działań resuscytacyjnych?”.

\section{Główne zasady etyczne}

Zasada autonomii pacjenta jest prawem pacjenta do wyrażania zgody na proponowane leczenie. Dotyczy osób świadomych, zdolnych do podejmowania decyzji, wyrażania jej. Warunkiem jest to, iż pacjent powinien być dobrze poinformowany, świadomy i nieulegający żadnym naciskom [14]. Skrajny wcześniak jest pacjentem niezdolnym do wyrażenia swej zgody na proponowane leczenie czy resuscytację. Głos w jego imieniu przejmują rodzice oraz zespół leczący. Rodzice mają prawo do pełnej informacji o stanie zdrowia swojego dziecka, aby móc świadomie wyrazić swoją opinię co do dalszego postępowania medycznego.

Zasada nieczynienia krzywdy oznacza, iż zespół medyczny powinien postępować tak, by nie działa się krzywda. Bądź szerzej - nie działa się większa krzywda. Oznacza działanie pracowników ochrony zdrowia w najlepszym interesie pacjenta. Zaleca ona rozwa- żenie korzyści i ryzyka [15]. W myśl tej zasady resuscytacja nie powinna być podejmowana w sytuacjach nierokujących powodzenia. Należy więc zrezygnować z uporczywej terapii.

Zasada sprawiedliwości (uczciwości i równości) oznacza obowiązek sprawiedliwego i równego rozłożenia ograniczonych możliwości leczniczych w społeczeństwie. Resuscytacja powinna być dostępna dla każdego człowieka, jeśli tylko jest w stanie przynieść mu korzyść [14].

Zgodnie z zasadą godności i uczciwości leczenie pacjenta powinno zawsze odbywać się z poszanowaniem jego osoby [16]. Przekazywane informacje powinny być pełne, bez pomijania ważnych faktów. Lekarz/położna powinni mówić językiem zrozumiałym dla pacjenta. Kodeks etyki ICN dla pielęgniarek (2000) odzwierciedla profesjonalne wartości zawodowe w stwierdzeniu: „ściśle związanym z pielęgniarstwem jest szacunek dla praw człowieka, włączając w to prawo do życia, zachowania godności i traktowania z szacunkiem" [17].

\section{Zasada świętości życia ludzkiego - podsumowanie}

Debatując na temat tego, że człowiek ma prawo do zdrowia i szczęścia, przywołajmy jeszcze jeden fakt - człowiek ma prawo do życia. Tego prawa nie naruszają ograniczenia psychiczne czy fizyczne osoby ludzkiej. Wszelkich podstaw pozbawione jest twierdzenie, iż chory noworodek urodzony przed czasem nie może być uważany za „osobę". Wszelkie zatem działania muszą się mieścić w granicach szacunku dla jego życia. Według nauczania Kościoła katolickiego przyznajemy osobowe prawa człowiekowi już od chwili zapłodnienia. Te same prawa głosi zasada świętości życia ludzkiego. Życie jest darem Boga. W encyklice Evangelium Vitae papież Jan Paweł II uzasadnia: świętość ludzkiego życia jest skutkiem trzech powiązanych ze sobą zdarzeń pełnego miłości „zejścia” Boga do człowieka, Boskiego współuczestnictwa w akcie małżeńskim, dającego początek indywidualnemu osobowemu istnieniu oraz „wychodzenia" tak poczętego człowieka do Stwórcy i partycypacji w jego życiu. Prawo świętości życia uzasadnia zakaz zabijania, sankcjonuje prawo człowieka do życia - od zapłodnienia do naturalnej śmierci. Strzeże ono daru życia jako stanu wyróżnionego moralnie, które należy chronić, gdyż jest cenne samo w sobie [18].

\section{Piśmiennictwo}

1. Mepham B. Bioetyka. Warszawa: PWN; 2008.104.

2. Środa M. $O$ wartościach moralnych i problemach moralnych. Warszawa: PWN; 1994. 21.

3. Ossowska M. Socjologia moralności. Warszawa: PWN; 1963. 178

4. Ossowska M. Normy moralne. Warszawa: PWN; 2000. 25-26. 
5. Żydowo M. Problemy naukowe współczesności. Etyczne problemy wynikające z rozwoju nauki. Warszawa: PAN, Centrum Upowszechniania Nauki; 2003. 243.

6. Czyżewska M. Neonatologia, podręcznik dla studentów Wydziału Zdrowia Publicznego. Wrocław: AM im. Piastów Śląskich; 2007. 54.

7. Bręborowicz GH. Położnictwo. Podręcznik dla położnych i pielęgniarek. Warszawa: PZWL; 2005. 435.

8. Perlman JW, Kattwinkel J, Atkins DL, Chameides L, Goldsmith JP, Guinsburg R, Hazinski MF, Morley C, Richmond S, Simon WM, Singhal N, Szyld E, Tamura M, Velaphi S. European Resuscitation Council Guidelines for Resuscitation 2010. Section 7. Resuscitation of babies at birth, http:// nagle.mp.pl/wytyczne/show.html?id=60270\&print=1 (data dostępu: 22.11.2016).

9. Gadzinowski J, Jopek A. Neonatologia - między etyką a pragmatyzmem. Nauka. 2007; 3: 21.

10. Szewczyk K. Decyzje krytyczne w neonatologii i standardy ich podejmowania. Diametros. 2010; 26: 98.

11. Pietrzykowski T. Spór o eutanazję, etyczne problemy prawa. Katowice: Wyd. Sonia Draga; 2007. 21-23.

12. Ślipko T. Bioetyka. Najważniejsze problemy. Kraków: Wyd. Petrus; 2009. 118-119.

13. Grudzień A, Kwinta P, Lauterbach R, Pietrzyk JJ. Czy zmieniło się rokowanie co do przeżycia i występowania powikłań u noworodków ze skrajnie małą masą ciała urodzonych w województwie małopolskim w latach 2006-2008 w porównaniu z okresem 2002-2004? Post Neonatol. 2012; 2(18): 32.
14. Etyka resuscytacji oraz problemy końca życia. Kraków: Polska Rada Resuscytacji; 2010. 280, http://www.prc.krakow. pl/2010/10.pdf (data dostępu: 23.08.2016).

15. Frączek B, Cebula G, Andres J. Etyka w resuscytacji. Na Ratunek. 2011; 5: 46.

16. Powszechna Deklaracja Praw Człowieka, http://www.unesco.pl/fileadmin/user_upload/pdf/Powszechna_Deklaracja_Praw_Czlowieka.pdf (data dostępu: 23.08.2016).

17. Fry S, Johastone M. Etyka w praktyce pielęgniarskiej. Zasady podejmowania decyzji etycznych. Warszawa-Lublin: Wyd. Makmed; 2009. 23.

18. Szewczyk K. Bioetyka. Medycyna na granicach życia. Warszawa: PWN; 2009. 249-250.

Artykuł przyjęty do redakcji: 21.09.2016

Artykuł przyjęty do publikacji: 16.12.2016

Źródło finansowania: Praca nie jest finansowana z żadnego źródła. Konflikt interesów: Autorzy deklarują brak konfliktu interesów.

Adres do korespondencji:

Magdalena Napiórkowska-Orkisz

Tułodziad 14

14-120 Dąbrówno

tel. kom.: 607107391

e-mail: naporkowska-orkisz@wp.pl 